\title{
BENCANA BANJIR BANDANG DI GARUT 20 SEPTEMBER 2016
}

\section{FLASH FLOOD DISASTER IN GARUT 20 SEPTEMBER 2016}

\author{
Iwan G. Tejakusuma ${ }^{1}$
}

\begin{abstract}
ABSTRAK: Bencana banjir bandang terjadi di Garut pada 20 September 2016. Bencana ini merupakan bencana terbesar dalam sejarah kota ini dan menimbulkan korban jiwa sebanyak 33 orang tewas, 20 orang hilang tersapu aliran banjir bandang dan lebih dari 6300 orang mengungsi serta sekitar 2000 rumah mengalami kerusakan. Curah hujan yang sangat tinggi hingga mencapai di atas $150 \mathrm{~mm}$ atau tergolong ekstrim terjadi di hulu dan tengah Daerah Aliran Sungai Cimanuk. Perubahan penggunaan lahan dari hutan menjadi perkebunan menyebabkan run off menjadi semakin besar dan menyumbang faktor yang signifikan dalam terjadinya banjir bandang. Morfologi sungai berkelok pada setelah morfologi perbukitan dan pegunungan serta perkembangan permukiman di tepi sungai memberikan efek tingginya risiko bencana di Garut. Kombinasi curah hujan yang tinggi, perubahan penggunaan lahan dan morfologi sungai yang disertai dengan perkembangan permukiman di tepi sungai yang tidak ditata dengan baik menjadi faktor dominan untuk terjadinya bencana banjir bandang di Garut.
\end{abstract}

Kata kunci: banjir bandang, curah hujan, perubahan penggunaan lahan, perubahan iklim, morfologi sungai.

\begin{abstract}
Flash flood disaster occurred in Garut on 20 September 2016. The disaster is the biggest disaster in the history of this city in which 33 people were killed, 20 people were missing, 6300 people have been evacuated and 2.000 houses were damaged. Rainfall is very high, reaching over $150 \mathrm{~mm}$ or relatively extreme occurred in the upper and middle Cimanuk Watershed. Land use change from forest to plantations cause run-off becomes increasingly large and significant contributing factor in the occurrence of flash floods. The winding river morphology after morphological hills and mountains as well as the development of settlements on the river banks give the effect of disaster risks in Garut. The combination of high rainfall, changes in land use and river morphology conditions accompanied by the development of settlements on the river bank which is not well regulated are the dominant factors for the occurrence of flash flood disaster in Garut.
\end{abstract}

Keywords: flash flood, rainfall rate, land use change, climate change, river morfology.

1. PTRRB - TPSA - BPPT, JI. M. H. Thamrin No. 8, Jakarta 10340.

email: itejakusuma@yahoo.com 


\section{PENDAHULUAN}

Bencana banjir bandang di Indonesia semakin sering terjadi dan telah menimbulkan kerugian harta benda yang besar serta korban jiwa yang banyak. Bencana yang lebih dulu sering terjadi adalah bencana longsor dan bencana banjir yang merupakan jenis bencana yang paling banyak terjadi di Indonesia. Bencana banjir bandang kemudian menjadi kerap terjadi akibat beberapa faktor yang utamanya disebabkan oleh aktivitas manusia. Menurut UNISDR (https://www. unisdr.org/ we/inform/terminology\#letter-h) bencana banjir bandang digolongkan sebagai bencana hidrometeorologi. Bencana ini didefinisikan sebagai bencana akibat proses atau fenomena atmosfer, hidrologi atau oseanografi yang dapat menyebabkan hilangnya nyawa, cedera atau dampak kesehatan lainnya, kerusakan harta benda, kehilangan mata pencaharian dan pelayanan umum, gangguan sosial dan ekonomi, atau kerusakan lingkungan. Bahaya hidrometeorologi termasuk siklon tropis (juga dikenal sebagai topan dan angin puting beliung), badai, hujan es batu, angin tornado, badai salju, hujan salju yang berat, longsoran, badai pesisir, banjir termasuk banjir bandang, kekeringan, gelombang panas dan dingin. Kondisi hidrometeorologi juga dapat menjadi faktor dalam bahaya lain seperti tanah longsor, kebakaran liar, wabah belalang, epidemi dan transportasi dan penyebaran zat beracun dan material letusan gunung berapi.

Kejadian banjir bandang beberapa waktu belakangan ini bahkan terjadi pada daerah daerah yang sama sekali tidak diperkirakan. Sebagai contohnya adalah bencana banjir bandang yang terjadi di Garut pada 20 September 2016. Bencana ini menjadi perhatian besar karena kejadiannya yang tidak diprediksi akan terjadi di Kota Garut yang padat penduduknya. Oleh karena itu menjadi penting dan menarik untuk dikaji mengapa banjir bandang dapat terjadi di Garut terlebih lagi bencana ini telah bukan hanya menyebabkan kerugian harta benda dan sosial ekonomi namun juga korban jiwa yang banyak.
Tulisan ini mengkaji dan menganalisis tentang kejadian banjir bandang dan aspek penting yang mempengaruhinya Hasil kajian ini akan sangat penting sebagai pelajaran bukan hanya bagi masyarakat di Kabupaten dan Kota Garut serta para pemangku kepentingannya, namun juga untuk daerah lain di Indonesia.

\section{METODE}

Kajian tentang bencana banjir bandang di Garut 20 September 2016 ini dilakukan berdasarkan beberapa metode sebagai berikut:

- Melakukan studi literatur dari pustaka yang ada baik berupa data maupun informasi serta melakukan penelusuran literatur melalui jaringan internet.

- Melakukan kajian kronologis kejadian bencana banjir bandang.

- Melakukan analisis faktor terjadinya banjir bandang.

- Melakukan riset perbandingan dengan lokasi lainnya tentang banjir ekstrem dan banjir bandang.

- Menguraikan pelajaran penting yang dapat diambil dari bencana ini.

- Mengambil kesimpulan tentang banjir bandang di Garut 20 September 2016.

\section{HASIL DAN PEMBAHASAN}

\subsection{Kejadian Dan Kronologis Banjir Bandang Garut}

Bencana banjir bandang terjadi di Garut pada 20 September 2016. Bencana ini telah menimbulkan korban jiwa sebanyak 33 orang tewas dan 20 orang hilang tersapu aliran banjir bandang dan lebih dari 6300 orang mengungsi serta sekitar 2000 rumah mengalami kerusakan (http://www.antaranews .com/berita/586529/ bnpb-20-korban-masih-hilang-akibat-banjirbandang-garut). Daerah yang terkena banjir bandang meliputi 7 Kecamatan di Kabupaten Garut yaitu Kecamatan Bayongbong, Garut Kota, Banyu Resmi, Tarogong Kaler, Tarogong Kidul, Karang Pawitan dan Samarang. Banjir 
bandang ini merupakan banjir bandang terparah dan terbesar sepanjang sejarah Kabupaten Garut. Diketahui bahwa banjir bandang pernah juga terjadi pada tahun 1900 dan $\quad 1921 \quad$ (https://m.tempo.co/read/ news/2016/10/10/058811063/tim-itb-bikinrekonstruksi-banjir-bandang-garut). Kejadian itu telah jauh berlangsung lama sebelumnya atau 95 tahun yang lalu sehingga kondisi baik hutan dan lahan maupun atmosfernya jauh berbeda dengan tahun 2016. Pada tahun 1900 dan 1921 tersebut tentu penduduk yang menempati daerah Kabupaten Garut masih sangat sedikit. Demikian pula penduduk yang tinggal di dekat aliran Sungai Cimanuk, sehingga dampak yang ditimbulkan pada penduduk juga kecil. Namun demikian sejalan dengan waktu, terjadi pertambahan penduduk dan daerah pinggiran sungai ternyata menjadi daerah favorit untuk permukiman dan kegiatan sosial ekonomi penduduk. Daerah inilah yang kemudian menjadi lokasi terparah terkena aliran banjir bandang. Penduduk tinggal terlalu dekat dengan sungai yang semestinya ada sempadan sungai yang seharusnya menjadi daerah konservasi yang tidak boleh dibangun.

Bencana banjir bandang di Garut ini diduga terjadi akibat curah hujan yang sangat tinggi. Akibatnya Sungai Cimanuk dan Sungai Cikamuri meluap. Hujan deras di daerah Garut dan sekitarnya terjadi mulai sekitar pukul 19:00 WIB (Waktu Indonesia Bagian Barat) Selasa malam, 20 September 2016. Curah hujan ini berlangsung sekitar 4 jam hingga sekitar pukul 23:00 WIB dan air mulai masuk ke rumahrumah penduduk sekitar pukul 23:00 WIB. Aliran banjir bandang yang datang, merendam dan menghantam rumah rumah penduduk yang ada ditepi aliran Sungai Cimanuk yang berkelok-kelok. Daerah terparah yang terdampak terdapat pada tepi aliran sungai dan juga terutama pada belokan sungai. Bukan hanya harta benda seperti mobil, motor dan rumah namun juga penduduk serta ternak yang ada tersapu aliran banjir bandang ini. Sebagian warga yang tidak dapat menyelamatkan diri akhirnya tewas dan hilang terbawa arus banjir bandang. Berdasarkan cerita saksi mata penduduk yang nyaris tewas terbawa hanyut terjangan banjir bandang yaitu Mimin Aminah di Kampung Bojong Sudika, Kelurahan Haur Panggung, Kecamatan Tarogong Kidul dalam http://www.bbc.com/indonesia/berita_indone sia/2016/09/160923_indonesia_garut_ diketahui bahwa aliran banjir bandang datang dengan cepat dan dengan aliran yang sangat deras sehingga menggetarkan bangunan dan menghanyutkan bangunan rumahnya serta rumah disekitarnya. Mimin dan anaknya berusaha menyelamatkan diri dengan naik ke atas atap rumahnya kemudian berpindahpindah di atap rumah yang satu ke yang lainnya karena aliran banjir bandang menggetarkan rumah dan bahkan menghanyutkan rumah Mimin dan rumah yang berada didekatnya. Berdasarkan cerita ini maka dapat diprediksi bahwa tinggi aliran banjir bandang mencapai sekitar 4 meter dengan kecepatan yang tinggi sehingga mampu menghanyutkan rumah.

Kondisi pasca banjir bandang pada daerah terdampak dapat dilihat pada gambar 1, gambar 2, gambar 3 dan gambar 4 . Pada gambar tersebut terlihat kondisi permukiman penduduk yang porak poranda akibat hantaman aliran banjir bandang. Rumah penduduk bukan hanya rusak tapi juga hanyut terbawa arus banjir bandang yang kuat.

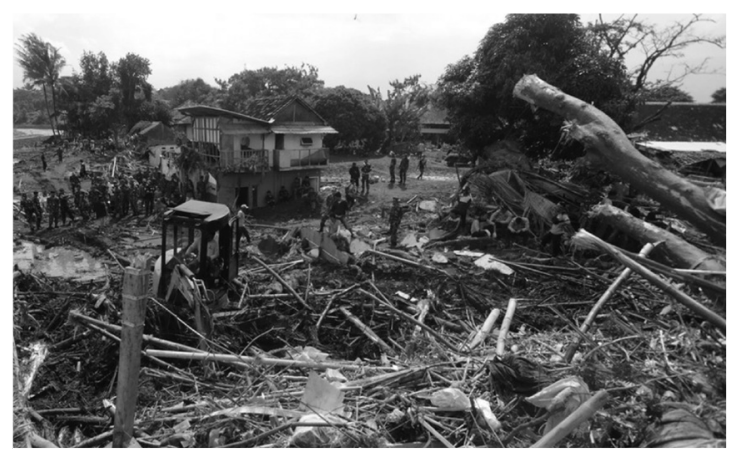

Gambar 1. Kondisi pasca banjir bandang di Kampung Cimacan, yang rusak parah akibat banjir bandang. (http://news.okezone.com/read /2016/09/22/525/1495764/bmkghujan-di-garut-tergolongekstrem). 
Analisis kejadian banjir bandang tidak dapat dilepaskan dari analisis tentang kondisi Daerah Aliran Sungai (DAS) dan kondisi lingkungan sungai itu sendiri. Daerah Garut termasuk ke dalam DAS Cimanuk, oleh karena itu pengetahuan tentang kondisi DAS Cimanuk sangat penting untuk analisis. Daerah Aliran Sungai Cimanuk berawal dari Gunung Puncakgede hingga pertemuan dengan Sungai Cilutung di Tomo memiliki luas 1.981 km2 (Sulaksana et al, 2013). Menurut data yang didapatkan dari https://www.monga bay.co.id/2016/09/30/banjir-das-cimanuk-alihfungsi-kawasan-yang-buruk/ diketahui bahwa DAS Cimanuk telah mengalami perubahan fungsi lahan yang besar. Alih fungsi lahan di daerah hulu terjadi ketika program Pengelolaan Hutan Bersama Masyarakat (PHBM) dari Perum Perhutani bergulir.

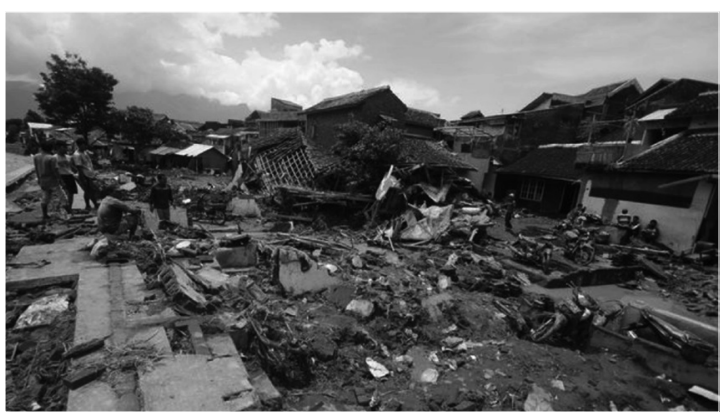

Gambar 2. Kondisi rumah warga yang rusak berat di tepi Sungai Cimanuk yang diterjang banjir bandang.

(http://news.okezone.com/read/ 2016/1018/525/1518048kerugian -akibat-banjir-bandang-garutditaksir-mencapai-rp288-m).

Kegiatan ini bertujuan untuk memberdayakan masyarakat dengan memanfaatkan ruang hutan dari aspek ekologi dan ekonomi. Namun demikian pada prakteknya pengawasan dan kontrol lemah sehingga terjadi pembukaan lahan hutan secara sporadis dan tidak terkendali. Perlu dilakukan pendidikan pada masyarakat akan pentingnya konservasi dan daya dukung lingkungan. Lahan dengan kemiringan di atas 30 derajat semestinya tidak digarap namun ternyata banyak dijumpai holtikultura dan palawija. Kondisi ini sebagai contohnya dapat dilihat pada gambar 5. Pembukaan daerah hutan dan alih fungsi lahan akan berakibat pada perubahan keseimbangan hidrologi di DAS.

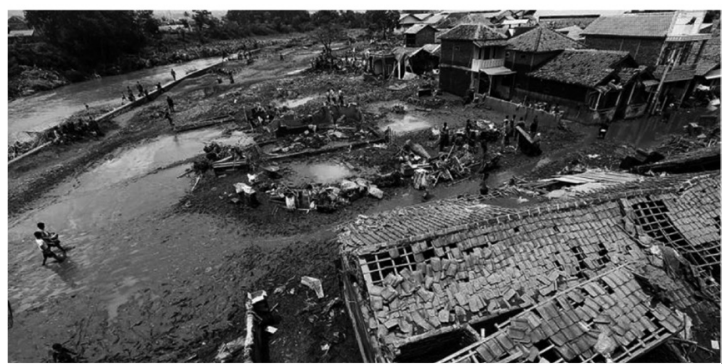

Gambar 3. Kondisi rumah warga yang rusak berat dan sebagian hanyut diterjang banjir bandang di tepi Sungai Cimanuk.

(http://regional.kompas.com/ read/2016/10/26/19584561/ pasca-banjir.bandanggarut.butuh .rp.626.3.miliar.untuk.pemulihan).

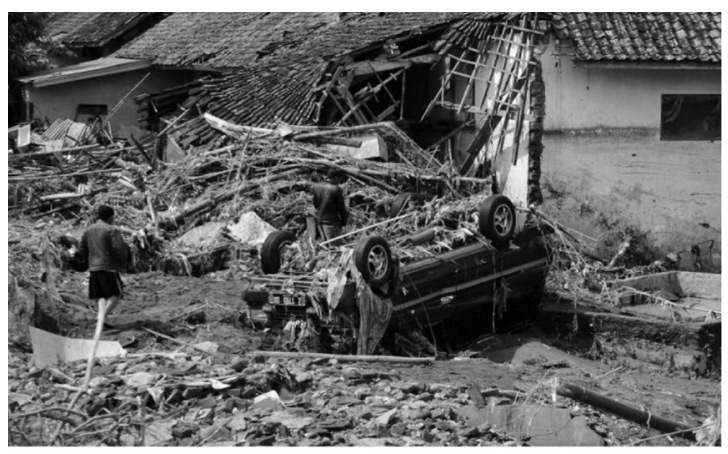

Gambar 4. Banjir bandang mengakibatkan sejumlah kendaraan hanyut dan terbalik.

(https://beritagar.id/artikel/berita lamuk-sungai-cimanuk-yangkian-kritis-di-garut). 


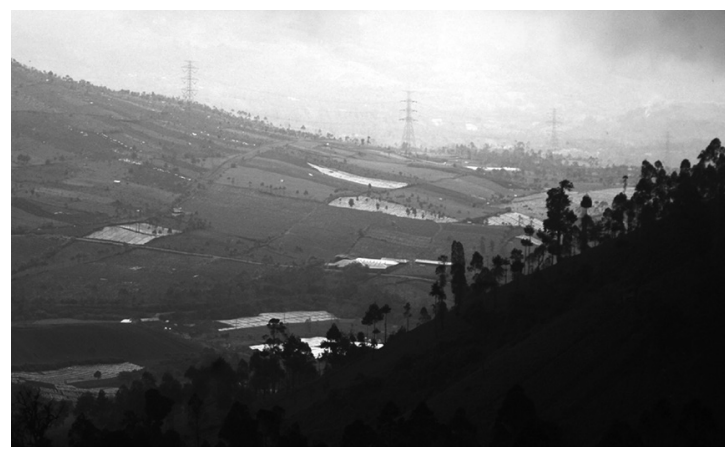

Gambar 5. Kondisi daerah resapan air yang beralih fungsi menjadi lahan pertanian di Kawasan Darajat, Kabupaten Garut, Jabar.

(https://www.mongabay.co.id/ 2016/09/30/banjir-das-cimanuk -alih-fungsi-kawasan-yangburuk/).

\subsection{Analisis Faktor Terjadinya Banjir Bandang}

Banjir bandang dalam prosesnya berhubungan erat dengan curah hujan. Berdasarkan data yang didapatkan diketahui bahwa curah hujan pada waktu sebelum dan hingga terjadinya banjir bandang adalah 255 milimeter kubik per detik (http://wartakota. tribunnews.com/2016/09/22/inilah-penyebabutama-banjir-bandang-di-garut).

Dalam klasifikasi tingkat curah hujan diketahui bahwa curah hujan 0-25 milimeter kubik per detik dikategorikan sebagai curah hujan yang rendah, 25-50 milimeter kubik per detik sedang, dan 50-100 milimeter kubik per detik curah hujan tinggi. Oleh karena itu curah hujan yang terjadi di Garut dan sekitarnya adalah tergolong sangat tinggi jauh melebihi tingkat curah hujan tinggi atau sekitar 2,5 kali lipat lebih yang turun hanya dalam kurun waktu 4 jam. Sementara itu juga diketahui bahwa Bendungan Copong di Sukasenang meluap karena hanya mampu menampung 740 meter kubik per detik, sementara air hujan yang tertampung mencapai 1.100 meter kubik per detik (http://wartakota.tribunnews. com/2016/09/22/inilah-penyebab-utama- banjir-bandang-di-garut). Menurut Pahlevi dan Zulfiani (2016), La Nina lemah, negatif IOD (Indian Ocean Dipole) dan MJO (MaddenJulian Oscillation) fase 5 pada 20 September 2016 menyebabkan menyebabkan massa udara dari Samudera Pasifik dan Samudera Hindia berkumpul di wilayah Indonesia. Sementara itu anomali suhu muka Laut Jawa menyebabkan penguapan dan pertumbuhan awan yang cepat. Pertumbuhan dan matinya awan Cumulonimbus yang begitu cepat menyebabkan hujan yang terjadi tergolong ke dalam hujan lebat. Hujan lebat tersebut yang menyebabkan terjadinya banjir bandang di wilayah Garut. Menurut data curah hujan BMKG (2016) dari jaringan penakar hujan yang ada di Kabupaten Garut maka dapat digambarkan secara spasial curah hujan yang terjadi di kabupaten ini pada 20 September 2016 (lihat gambar 6). Menurut data ini, curah hujan yang terjadi di wilayah hulu dan tengah kabupaten ini tergolong dalam hujan lebat (50 - $100 \mathrm{~mm} /$ hari), sangat lebat $(100-150$ $\mathrm{mm} /$ hari) hingga ekstrem (>150 mm/hari). Menurut data di http://news.okezone.com/ read/2016/09/22/525/1495764/bmkg-hujandi-garut-tergolong-ekstrem, kalau ditotalkan selama 10 hari terakhir sebelum dan pada waktu banjir bandang terjadi, curah hujan mencapai 500 milimeter yang tergolong ekstrem. Hujan yang turun akan sampai di permukaan bumi dan kemudian sebagian menyerap ke dalam tanah, mengalir di permukaan berupa sungaisungai atau tertahan di kolam atau danau dan sebagian menguap kembali. Kondisi tutupan lahan sangat berpengaruh terhadap jumlah curah hujan yang kemudian mengalir sebagai aliran permukaan.

$$
\text { Menurut Wulandari (2008), }
$$

dalam penelitiannya tentang pengaruh penggunaan lahan terhadap debit aliran sungai menemukan bahwa Daerah Tangkapan Air Hulu Cimanuk yang sebagian besar penggunaan lahannya didominasi oleh kebun campuran dan ladang serta terdapatnya hutan pinus belum mampu mengurangi fluktuasi debit tahun 2006, sehingga mengakibatkan 
terjadinya kekurangan air pada musim kemarau dengan nilai koefisien aliran sebesar $51,1 \%$.

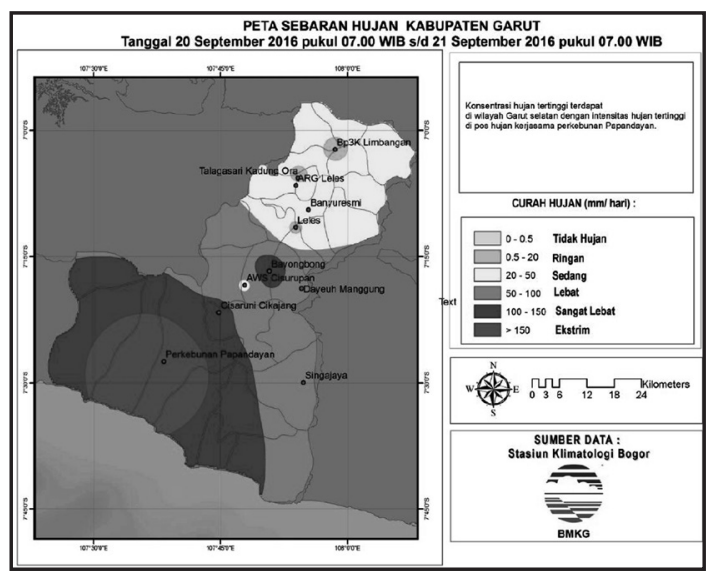

Gambar 6. Curah hujan yang terjadi di wilayah Kabupaten Garut pada 20 September 2016 menurut Badan Meteorologi Klimatologi dan Geofisika (2016).

Sementara itu Raharsiani (2013) dalam penelitiannya menunjukkan bahwa perubahan penggunaan lahan di Sub DAS Cimanuk Hulu berpengaruh secara signifikan terhadap debit aliran dan sedimentasi, yakni berkurangnya lahan hutan seluas 3.284 ha, bertambahnya lahan pertanian seluas 2.881 ha, dan bertambahnya lahan perkotaan seluas 403 ha meningkatkan debitaliran rata-rata sebesar 11,3 $\mathrm{m} 3$ /detik serta peningkatan sedimen di sungai sebesar 41.085 ton. Sulaksana et al (2013) menerangkan bahwa litologi daerah Cimanuk bagian hulu didominasi oleh produk vulkanik berumur Kwarter yang belum terkompaksi dengan baik sehingga mudah hancur dan rentan terhadap erosi. Litologinya tersusun oleh lanau plastisitas tinggi (40\%), lanau pasiran $(33 \%)$, dan lempung plastisitas tinggi $(27 \%)$. Lanau dan lanau pasiran relatif mudah tererosi dibandingkan lempung dan kombinasi antara litologi beserta hasil pelapukannya dan tektonik aktif yang mengontrol DAS Cimanuk bagian hulu berperan dalam meningkatnya intensitas erosi. Geomorfologi dan topografi daerah Garut dan sekitarnya memiliki jarak antara daerah lereng dan lembah yang dekat. Di Sungai Cimanuk, hanya dalam waktu dua sampai tiga jam air dapat sampai ke Tarogong Kidul. Topografi yang curam, resapan air yang minim mengakibatkan percepatan air mengalir dengan deras. Sebagai perbandingan, di Bandung, saat terjadi hujan deras, air Sungai Citarum sampai ke Dayeuh Kolot setelah lima sampai enam jam (https://www.mongabay. co.id/2016/09/23/memprihatinkan-ternyata-inipenyebab-banjir-bandang-garut/).

Menurut data dari https://www. mongabay. co.id/2016/09/21/banjir-bandanggarut-puluh an-tewas-bnpb-das-cimanukrusak-parah/ banjir bandang Garut diakibatkan oleh pengelolaan DAS Sungai Cimanuk yang buruk. Parameter Koefisien Regim Sungai (KRS) Cimanuk ada di atas batas normal. KRS adalah angka yang menunjukkan perbandingan antara nilai debit maksimum dengan debit minimum pada suatu DAS atau sub-DAS. Debit maksimum, merupakan debit sungai pada saat banjir dan sebaliknya debit minimum terjadi pada saat kemarau. Kategori KRS baik memiliki nilai 40 , kategori sedang nilainya 40-80 sedangkan kategori buruk nilainya lebih dari 80 . KRS Cimanuk ini nilainya adalah 713 , oleh karena itu ternasuk kategori buruk bahkan diketahui bahwa KRS sungai ini merupakan yang paling buruk di Pulau Jawa. Situasi ini sudah berlangsung sejak tahun 1980. Sebagai perbandingan kondisi KRS di daerah lain di Pulau Jawa yang pada umumnya kritis adalah Sungai Bengawan Solo (KRS 541), Sungai Brantas, Malang (KRS 205) dan Sungai Ciujung, Banten (KRS 189,5). Untuk meminimalkan potensi banjir dan longsor diperlukan upaya pengembalian fungsi ekosistem lingkungan DAS.

\subsection{Riset Banjir Bandang}

Kejadian banjir bandang semakin sering terjadi di Indonesia dan di dunia akibat kombinasi dari beberapa faktor utamanya adalah perubahan iklim dan bertambahnya populasi penduduk yang menyebabkan 
perubahan penggunaan lahan. Pengaruh perubahan penggunaan guna lahan dengan banjir dan banjir bandang juga diketahui dari beberapa studi yang dilakukan di daerah lain. Bingwa (2013) melakukan studi di DAS Manafwa, Uganda dan menemukan bahwa perubahan penggunaan guna lahan mempengaruhi aliran sungai dimana frekuensi banjir menjadi semakin tinggi dan penghutanan kembali dapat menurunkan risiko banjir di DAS.

Van der Ploeg et al (2000) dalam penelitiannya menemukan bahwa meningkatnya frekuensi banjir dan banjir bandang pada sungai-sungai utama di Jerman yang biasa terjadi pada musim dingin dan basah adalah juga disebabkan oleh perubahan penggunaan guna lahan. Daerah padang rumput di daerah Jerman Barat menurun dari tahun 1951 hingga 1989 dari $15,7 \%$ menjadi $10,8 \%$. Bersamaan dengan itu daerah pertanian tanaman pangan meningkat dari $18,5 \%$ menjadi $22,3 \%$. Selain itu, hampir $20 \%$ dari luas lahan pertanian terkuras secara artifisial selama periode ini. Selain itu daerah perkotaan termasuk sistem jalannya meningkat antara tahun 1951 dan 1989 dari 7,4\% menjadi $12,2 \%$. Fakor yang dapat meningkatkan run off atau aliran permukaan adalah degradasi tanah secara fisik (kerusakan struktur tanah yang menyebabkan terjadinya slaking dan penutupan permukaan saat hujan deras) dan pemadatan tanah. Bencana banjir dan banjir bandang serta kerusakan yang ditimbulkan akibat banjir cenderung meningkat dari tahun ke tahun akibat perubahan iklim dan perubahan penggunaan lahan. Feyen et al, (2003) menyatakan bahwa jumlah kerusakan dan kerugian yang ditimbulkan akibat banjir karena ekspansi atau semakin berkembangnya perkotaan jauh melebihi efek dari perubahan iklim itu sendiri.

Kejadian banjir bandang tidak selalu disebabkan utamanya oleh perubahan penggunaan lahan. Penelitian yang dilakukan oleh Billi et al (2015) di Ethiopia tentang meningkatnya frekuensi kejadian banjir bandang di Kota Dire Dawa yang dilalui oleh Sungai Dechatu menunjukkan bahwa ternyata faktor curah hujan memegang peranan yang lebih penting bila dibandingkan dengan perubahan penggunaan lahan. Sementara itu, Rukundo dan Ahmet (2016) juga melakukan penelitian tentang pengkajian iklim dan projeksi perubahan penggunaan lahan serta dampaknya pada banjir ekstrim di Kota Kigali, Rwanda. Hasil risetnya menunjukkan bahwa perubahan iklim berpengaruh pada penurunan ekspektasi puncak banjir sementara perubahan penggunaan lahan mempunyai dampak signifikan pada peningkatan banjir. Dampak perubahan penggunaan lahan pada banjir lebih dominan dari dampak perubahan iklim pada banjir.

Berdasarkan beberapa riset tersebut dapat disimpulkan bahwa perubahan penggunaan lahan dan perubahan iklim memegang peranan yang penting dalam terjadinya banjir ekstrem dan banjir bandang. Oleh karena itu mitigasi banjir bandang tidak dapat dilepaskan bagaimana menangani dua faktor tersebut. Faktor perubahan iklim tentu lebih sulit untuk ditangani karena bersifat regional dan global. Oleh karena itu faktor penggunaan lahan dan juga penggunaan lahan akibat aktivitas manusia termasuk perkembangan permukiman dan infrastruktur lain harus mempertimbangkan potensi terjadinya banjir bandang.

\subsection{Pelajaran Dari Bencana Banjir Bandang Di Garut}

Bencana banjir bandang di Garut memberikan pelajaran yang sangat berharga baik bagi masyarakat Garut maupun bagi masyarakat daerah lainnya di Indonesia. Beberapa pelajaran penting yang dapat diambil dari kejadian ini adalah:

1. Kondisi cuaca dan curah hujan cenderung dapat berubah dengan relatif cepat dimana curah hujan yang sangat tinggi terjadi dengan durasi yang pendek. Kejadian di wilayah Garut yaitu pada 20 
September 2016 curah hujan seperti itu tidak harus terjadi dalam musim hujan. Kejadian ini dapat cenderung menjadi semakin sering terjadi dan diduga sebagai akibat perubahan iklim. Kondisi ini dapat terjadi di wilayah lain di Indonesia. Oleh karena itu peningkatan kesiapsiagaan menghadapi bencana banjir bandang perlu dilakukan terutama di daerah risiko tinggi.

2. Kondisi perubahan penggunaan lahan ternyata membawa akibat yang signifikan dalam terjadinya banjir bandang di Garut terlebih pada DAS dengan kemiringan lereng yang cukup besar dan litologi yang didominasi oleh lanau dan lempung yang relatif kedap air sehingga proses infiltrasi berjalan relatif lebih lambat.

3. Daerah tepi sungai dan kelokan sungai atau meander sungai merupakan daerah dengan risiko bencana banjir bandang yang tinggi.

4. Penataan ruang permukiman dan kegiatan sosial ekonomi di daerah sempadan sungai dan kelokan sungai memerlukan pengaturan yang serius dan tegas dengan memperhatikan kondisi lingkungan dan ancaman bencana yang mungkin terjadi.

5. Rehabilitasi dan konservasi lahan daerah tangkapan air dan daerah hulu perlu dilakukan dengan serius dan tegas dengan memperhatikan pemberdayaan penduduk.

\section{KESIMPULAN}

Berdasarkan hasil kajian, maka didapatkan beberapa kesimpulan tentang bencana banjir bandang yang terjadi di Garut pada 20 September 2016 sebagai berikut:

1. Banjir bandang telah menimbulkan korban jiwa sebanyak 33 orang tewas, 20 orang hilang tersapu aliran banjir bandang dan lebih dari 6300 orang mengungsi serta sekitar 2000 rumah mengalami kerusakan.
2. Kerugian ekonomi akibat bencana banjir bandang ini besar yaitu diperkirakan tidak kurang dari 288 Milyar Rupiah.

3. Bencana banjir bandang disebabkan oleh kombinasi faktor cuaca serta kondisi DAS Cimanuk dan juga permukiman yang berkembang di tepi dan dekat dengan sungai.

4. Curah hujan yang sangat tinggi atau ekstrem di daerah hulu dan tengah Daerah Aliran Sungai Cimanuk menjadi pemicu dan penyebab terjadinya banjir bandang.

5. Morfologi sungai berkelok segera setelah morfologi perbukitan dan pegunungan serta perkembangan permukiman di tepi sungai memberikan efek tingginya risiko bencana banjir bandang di Garut.

6. Kondisi perubahan penggunaan lahan di daerah hulu Sungai Cimanuk memberikan dampak yang signifikan untuk terjadinya banjir bandang dengan efek meningkatnya run off atau limpasan permukaan.

\section{DAFTAR PUSTAKA}

Badan Meteorologi dan Geofisika (BMKG), 2016, Peta Sebaran Hujan Kabupaten Garut Tanggal 20 September 2016 Pukul 07:00 WIB Sampai Dengan 21 September 2016 Pukul 07:00 WIB. Stasiun Klimatologi Bogor -BMKG.

Billi, Paolo; Yonas Alemu and Rossano Ciampalini, 2015, Increased Frequency of Flash Floods in Dire Dawa, Ethiopia: Change in Rainfall Intensity or Human Impact?, Natural Hazards: Journal of the International Society for the Prevention and Mitigation of Natural Hazards, 2015, vol. 76, issue 2, pages 1373-1394.

Bingwa, Fidele, 2013, A Quantitative Analysis of the Impact of Land use Changes on Floods in the Manafwa River Basin, Master of Engineering in Civil and Environmental Engineering Thesis, Massachusetts Institute of Technology, June 2013. 
Feyen, L.; Barredo, J.I.; Dankers, R., 2008, Implications of Global Warming and Urban Land Use Change on Floodings in Europe, in: Feyen, J. et al. (Ed.) (2009). Proceedings of The International Urban Water Conference, Heverlee, Belgium, 15-19 September, 2008: Water and Urban Development Paradigms Towards an Integration of Engineering, Design and Management Approaches, pp. 217-225.

http://news.okezone.com/read/2016/09/22 /525/1495764/bmkg-hujan-di-garuttergolong-ekstrem, diakses pada 30 September 2016.

http://regional.kompas.com/read/2016/10/ 26/19584561/pasca-banjir.bandang .garut.butuh.rp.626.3.miliar.untuk. pemulihan, diakses pada 6 Oktober 2016.

http://wartakota.tribunnews.com/2016/09/22/ inilah-penyebab-utama-banjir-bandangdi-garut, diakses pada 29 September 2016.

http://www.antaranews.com/berita/586529/ bnpb-20-korban-masih-hilang-akibatbanjir-bandang-garut, diakses pada 28 September 2016, diakses pada 3 Oktober 2016.

http://www.bbc.com/indonesia/berita_ indonesia/2016/09/160923_indonesia_ garut_, diakses pada 10 Oktober 2016.

https://beritagar.id/artikel/berita/amuk-sungaicimanuk-yang-kian-kritis-di-garut, diakses pada 14 Oktober 2016.

https://m.tempo.co/read/news/2016/10/ $10 / 058811063 / \mathrm{tim}$ - i t b - b ik in rekonstruksi-banjir-bandang-garut, diakses pada 18 Oktober 2016.

https://www.mongabay.co.id/2016/09/21/ banjir-bandang-garut-puluhan-tewasbnpb-das-cimanuk-rusak-parah/, diakses pada 25 Oktober 2016.

https://www.mongabay.co.id/2016/09/23/ memprihatinkan-ternyata-ini-penyebabbanjir-bandang-garut/, diakses 27 September 2016. https://www.mongabay.co.id/2016/09/30/ banjir-das-cimanuk-alih-fungsi-kawasanyang-buruk/, diakses pada 17 Oktober 2016.

https://www.unisdr.org/we/inform/ terminology\#letter-h, diakses pada 26 September 2016.

Pahlevi, A. R. dan A. Zulfiani, 2016, Analisis Kondisi Atmosfer Saat Terjadinya Banjir Bandang Di Garut (20 September 2016), http://www.bmkg.go.id/ artikel/?id=tsx58499210za5s12134.

Raharsiani, Riska, 2013, Strategi Pengelolaan Sub DAS Cimanuk Hulu (Studi Kasus: Perubahan Tataguna Lahan terhadap Debit Aliran dan Sedimentasi), Thesis, Universitas Padjadjaran, Bandung.

Rukundo, Emmanuel and Ahmet Doğan, 2016, Assessment of Climate and Land Use Change, Polish Journal of Environmental Studies, Vol. 25, No. 6 (2016), 2541-2551.

Sulaksana, N., Sukiyah, E., Sjafrudin, A. dan Haryanto, E.T., 2013, Karakteristik Geomorfologi DAS Cimanuk Bagian Hulu dan Implikasinya Terhadap Intensitas Erosi Serta Pendangkalan Waduk Jatigede, Bionatura-Jurnal IImu-ilmu Hayati dan Fisik, Vol. 15, No. 2, Juli 2013: 100 - 106. ISSN 1411 - 0903.

Van Der Ploeg, R. R., G. Machulla, D. Hermsmeyer, J. Ilsemann, M. Gieska and J. Bachmann, 2000, Changes in Land Use and the Growing Number of Flash Floods in Germany, Proceedings of a Symposium on Agricultural Effects on Ground and Surface Waters: Research at the Edge of Science and Society, Wageningen, October 2000.

Wulandari, G. R., 2008, Pengaruh Penggunaan Lahan terhadap Debit Aliran Sungai, Skripsi, Program Studi IImu Tanah, Fakultas Pertanian, Institut Pertanian Bogor. 